\title{
RESEARCH
}

Open Access

\section{Soil organic matter quality along rotations in acacia and eucalypt plantations in the Congolese coastal plains}

\author{
Lydie-Stella Koutika ${ }^{1,2^{*}} \mathbb{D}$, Sylvain Ngoyi ${ }^{1}$, Lorenzo Cafiero ${ }^{3}$ and Annamaria Bevivino ${ }^{2}$
}

\begin{abstract}
Background: Afforestation of savannas in the Congolese coastal plains with eucalypt has provided wood pulp for industry and fuel energy for the local population. Typically, following afforestation, Acacia mangium are introduced to improve soil fertility and sustain productivity. Through investigations of particulate organic matter (POM), potential soil organic matter (SOM) quality was assessed in acacia and eucalypt plantations along rotations.

Methods: Nutrients in POM $(4000-50 \mu \mathrm{m})$ in the $0-5 \mathrm{~cm}$ soil layer were measured after five years into the second rotation (R2Y5) in relation to soil pH and P availability. Data were compared to those at the end of the first 7-yearrotation (R1Y7) and after two years into the second rotation (R2Y2) to evaluate overall SOM quality in the topsoil.

Results: At R2Y5, soil pH was higher in the pure eucalypt stands (100E) than in stands containing acacia, either in monoculture (100A) or evenly mixed with eucalypt (50A50E). Coarse POM (CPOM, 4000-250 $\mu \mathrm{m}$ ) beneath 100A had the highest $N$ concentration (1.71\%), followed by those beneath 50A50E (1.42\%) and 100E (1.30\%). Higher N was always found in the stands containing acacia. Lower sulphur (S) concentrations and $\mathrm{P}$ availabilities were observed in CPOM (50A50E). The greatest amount of coarse $(414.7 \mathrm{~g})$ and fine $(214.5 \mathrm{~g})$ forest floor litter were found in 100A stands, whereas higher C concentrations were found in the 100E stands for coarse forest floor litter (36.5\%) and in the 50A50E stands for fine forest floor litter (38.7\%). The decrease in CPOM N and C concentrations were lower than $20 \%$ (R1Y7) and 26\% (R2Y5) relative to the younger stage (R2Y2). This tendency was more pronounced in fine POM $(250-50 \mu \mathrm{m})$ and organo-mineral fraction $(<50 \mu \mathrm{m})$.

Conclusions: The main changes occurred in CPOM beneath stands containing acacia while higher weight of forest floor litter was found in 100A. Soil pH decreased in stands containing acacia. Overall N and C dynamics was enhanced in older stands (R2Y5) than in the younger stands (R2Y2). This may reveal a creation of more labile SOM with lower $\mathrm{N}$ and $\mathrm{C}$ concentrations in POM fractions in the surface layer, i.e., an ecosystem with a lower potential to mitigate climate change along rotations.
\end{abstract}

Keywords: Particulate organic matter, Nitrogen, Carbon, Phosphorus, Sulphur, Nitrogen-fixing species, Fast growing tree, Climate change mitigation

\footnotetext{
*Correspondence: Is_koutika@yahoo.com

'Research Center on the Durability and the Productivity of Industrial Plantations (CRDPI), B.P. 1291 Pointe-Noire, Republic of the Congo

${ }^{2}$ Department for Sustainability, Biotechnologies and Agroindustry Division,

Laboratory for AgriFood Sustainability, Quality and Safety, Italian National

Agency for New Technologies, Energy and Sustainable Economic

Development, ENEA, Casaccia Research Centre, 00123 Rome, Italy

Full list of author information is available at the end of the article
} 


\section{Background}

Soil organic carbon (SOC) is the main component of soil organic matter (SOM) (Platteau et al. 2006; Lal 2008). Fluxes of $\mathrm{C}$ from soil to atmosphere are partially regulated by the physical, and chemical characteristics of this SOM (Stewart et al. 2009; Kirkby et al. 2013), and is linked to other nutrients such as N, P and S (Binkley 1992; Sang et al. 2013; Kopittke et al. 2017). Factors such as soil texture, climate and relief have an undeniable impact on SOC status, i.e., on SOM quality and quantity (Pieri 1989; Hassink et al. 1993; Koutika et al. 1999; Galantini et al. 2004). SOC sequestration, i.e., taking up atmospheric $\mathrm{CO}_{2}$ and converting it into soil $\mathrm{C}$ may potentially and simultaneously improve soil fertility, increase food and wood production and mitigate climate change (Lal 2004, 2008; www.4per1000.org). Land-use changes have a great impact on the status and dynamics of SOM and its further impact on SOC sequestration and climate change mitigation (Lal 2014). Land-use changes such as afforestation of unmanaged lands, pastures, savannas or cerrados alter SOM i.e., SOC inputs and decomposition, and, consequently, impact on $\mathrm{C}, \mathrm{N}$ and P dynamics (Gonçalves et al. 2008; Pérez-Cruzado et al. 2012; Forrester et al. 2013; Epron et al. 2015; Dou et al. 2016; Tchichelle et al. 2017; Koutika 2019).

In the 1950's, native tropical savannas on inherently nutrient-poor soils in the Congolese coastal plains in the Republic of the Congo have been afforested using fast growing eucalypt (Makany 1964) with the primary goals of providing both wood for the pulp industry and fuel energy for the rural population (Delwaulle et al. 1978, 1981). Currently these plantations greatly contribute to preserving natural forests, since around 94\% of Congolese homes use forest products as fuel in both wood and charcoal (Shure et al. 2010), and mitigate climate change by storing $\mathrm{C}$ in both soil and biomass i.e., increased soil $\mathrm{C}$ stocks and stand wood biomass (Epron et al. 2013; Koutika et al. 2014). Research conducted in the native tropical savannas in the Congolese coastal plains has regional importance. These savannas extend to around 6 million hectares in the countries of Central Africa, e.g., the Democratic Republic of the Congo, Gabon and the Republic of the Congo (Schwartz and Namri 2002). Nutrient supply in these inherently poor soils depends predominantly on decomposition of organic residues, since little or no replenishment is made with fertilizers (Laclau et al. 2005). Depletion in nutrient availability occurs rapidly after successive rotations inducing a decline in the productivity of fast-growing plantations (Laclau et al. 2005; Corbeels et al. 2005). As nitrogenfixing tree species (NFS), acacia has been introduced since the 1990s to restore and improve soil fertility and sustain the productivity of eucalypt plantations in the Congolese coastal plains (Bernhard-Reversat 1993; Bouillet et al. 2013; Epron et al. 2013; Koutika 2019).

During the past years, the benefits of mixed-species plantations of acacia and eucalypt in the Congolese coastal plains have been evaluated for multiple benefits, including (i) increased forest productivity (Bouillet et al. 2013; Epron et al. 2013); (ii) improved soil fertility i.e., increased cumulative net production of mineral $\mathrm{N}$, soil $\mathrm{N}$ concentration and stock in bulk soil and fractions (Koutika et al. 2014; Koutika et al. 2017; Tchichelle et al. 2017); and (iii) sequestered $C$ through increased soil $C$ stock and concentration in bulk soil and fractions, and biomass (Epron et al. 2013; Koutika et al. 2014; Koutika et al. 2017). Both soil $\mathrm{N}$ and $\mathrm{C}$ accretions have been reported in mixed-species plantations of NFS and nonfixing species worldwide (Resh et al. 2002; Binkley 2005; Forrester et al. 2013; Bauters et al. 2015). This is due to enhanced below- and aboveground biomass and forest growth as result of higher soil $\mathrm{N}$ availability, i.e., $\mathrm{N}$-fixation permits $\mathrm{C}$ accretion and tends to reduce $\mathrm{C}$ loss, thus contributing to climate change mitigation (Binkley 1992; Fornara et al. 2013). In addition to the above benefits reported in the Congolese coastal plains, an improvement in soil $\mathrm{P}$ status in the coarse fraction of $\mathrm{POM}$ (measured by an increase in resin extractable $\mathrm{P}$ in cPOM; 4000-250 $\mu \mathrm{m}$ ) has been noticed in afforested stands with acacia or/and eucalypt relative to native savannas (Koutika and Mareschal 2017; Koutika 2019). However, probably due to the high P demand in supplying symbiotic root nodules and $\mathrm{N}_{2}$ fixation processes of acacia trees (Binkley 1992; Inagaki et al. 2011), a decrease in $\mathrm{P}$ availability and soil $\mathrm{pH}$ in afforested stands with acacia alone or in mixture with eucalypt relative to pure eucalypt stands has been observed (Koutika et al. 2014; Koutika et al. 2016).

Particulate organic matter (POM) is an early SOM indicator for evaluating changes in different ecosystems, e.g., forests, pastures and cropping systems (Cambardella and Elliot 1992; Sikora et al. 1996). According to soil type and characteristics, POM status may be determined by physicochemical (Vanlauwe et al. 1999; Koutika et al. 2001) or physical procedures (Epron et al. 2015; Koutika et al. 2017). It is a useful parameter since it relates to labile SOM and responds readily to soil management when no changes have been yet noticed in the bulk soil (Koutika et al. 2001, 2002; Wander 2004). Removing both the aboveground litter and harvest residues reduces soil $\mathrm{C}$ accretion in monocultural eucalypt plantations in the long-term, where three rotations each of seven years, i.e., a total of 21 years were evaluated in the Congolese coastal plains (Epron et al. 2015).

This study determines SOM dynamics and changes in soil $\mathrm{pH}$ in the Ferallic arenosol along with rotations of acacia and eucalypt plantations established in the 
Congolese coastal plains. Five questions were addressed: (i) would SOM mineralisation be enhanced through POM $(4000-50 \mu \mathrm{m})$ mainly in the coarse fraction (4000-250 $\mu \mathrm{m}$ ); (ii) would P availability decrease beneath mixed-species plantations at year 5 of the second rotation? (iii) how would POM dynamics and soil $\mathrm{pH}$ change over time, i.e., from R1Y7 to R2Y2 and R2Y5, knowing that high amounts of litterfall, forest floor and harvest residues were left after the first harvest and had accumulated for five years into the second rotation? (iv) would the trend previously observed in the second rotation at R2Y2 compared with R1Y7, i.e., higher $\mathrm{N}$ concentration in coarse POM $(4000-250 \mu \mathrm{m})$ in afforested stands with acacia (100A and 50A50E) than in 100E, persist at R2Y5? and (v) how would changes in SOM status affect the potential of the ecosystem to mitigate climate change? To answer these questions we conducted the following analyses: (i) assessment of N, C and S concentration in bulk soil, POM fractions and forest floor, soil $\mathrm{pH}$ and available $\mathrm{P}$ status at year 5 of the second rotation (R2Y5); and (ii) evaluation of the overall SOM dynamics through POM (N, C and S concentration) status and changes in soil $\mathrm{pH}$, from the end of the first 7-yearrotation (R1Y7) to year 2 of the second rotation (R2Y2) till the current study (R2Y5).

\section{Materials and methods}

\section{Site description}

The experimental site is located on a plateau close to Tchissoko village in the Republic of the Congo, $35 \mathrm{~km}$ from Pointe-Noire $\left(4^{\circ} 44^{\prime} 41^{\prime \prime}\right.$ ' S \& $12^{\circ} 01^{\prime} 51^{\prime \prime}$ E, $100 \mathrm{~m}$ Alt.) on a deep Ferralic arenosol laying on geological bedrock composed of thick detritic layers of continental origin dated from the plio-pleistocene era. These soils are characterized by a low CEC $\left(<0.5 \mathrm{cmol}_{\mathrm{C}} \cdot \mathrm{kg}^{-1}\right)$, a high sand content ( $>90 \%$ of the mineral soil), very low clay and silt content ( $6 \%$ and $2 \%$, respectively) and low iron oxide content $(<1.5 \%$ of the bulk soil, Mareschal et al. 2011). They are acidic with low $\mathrm{C}(<1.2 \%)$ and $\mathrm{N}$ content (>0.06\%) (Koutika et al. 2014). The climate in the area is sub-equatorial with high mean annual air humidity and air temperature $\left(85 \%\right.$ and $25^{\circ} \mathrm{C}$, respectively) and low seasonal variation (about $2 \%$ and $5{ }^{\circ} \mathrm{C}$, respectively). Mean annual precipitation is $1200 \mathrm{~mm}$ with a dry season extending from June to September. The original vegetation was a native tropical savanna dominated by the $\mathrm{C}_{4}$ poaceae Loudetia arundinacea (Hochst.) Steud, which was afforested in 1984 with planted eucalypt hybrids.

An experimental trial was installed in May 2004, which included pure stands of Acacia mangium (100A) and of Eucalyptus urophylla $\times$ E. grandis $(100 \mathrm{E})$ and mixedspecies stands with $50 \%$ of acacia and $50 \%$ of eucalypt (50A50E) in five replicates (randomized block design) at a density of 800 trees $\cdot \mathrm{ha}^{-1}$. Each stand covered $1250 \mathrm{~m}^{2}$ and contained 100 trees $(10 \times 10)$ including two buffer rows and an inner part of 36 trees (Epron et al. 2013). This first rotation was harvested in January 2012 at seven years old. A second rotation was planted with the same design in March 2012 (Koutika et al. 2016; Tchichelle et al. 2017).

\section{Forest floor}

The forest floor litter was sampled in May 2017 with a square metallic frame $(50 \mathrm{~cm} \times 50 \mathrm{~cm})$ on $4-6$ locations within each stand. The samples were oven-dried at $65^{\circ} \mathrm{C}$ during $72 \mathrm{~h}$ and weighed. The forest floor nitrogen $\left(\mathrm{kg} \cdot \mathrm{m}^{-2}\right.$ of $\left.\mathrm{N}\right)$ was calculated from the dry mass. N, C and $\mathrm{S}$ concentrations was evaluated using a Macro VARIO Cube Elemental Analyser (Germany) (see Epron et al. 2013; for details), while and P availability was determined by resin extraction (see more details below).

\section{Soil and forest floor analyses Soil sampling}

As most soil organic matter is concentrated in the upper layer in the area (d'Annunzio et al. 2008), soil was collected with an auger at 0-0.05 m depth in March 2017 at year 5 of the second rotation (R2Y5). Soil was sampled beneath three stands, the pure acacia (100A), and eucalypt (100E), and mixed-species (50\% acacia and 50\% eucalypt, 50A50E) in nine replicates by stands in three out of the five blocks. Three transects in $100 \mathrm{~A}$ and $100 \mathrm{E}$ stands and six in 50A50E stands were set up in the inner part of each stand, starting at the base of a tree and ending in the center of the area delimited by four trees. Three cores were sampled on each transect, each sampling point being separated by $0.7 \mathrm{~m}$ from each other along the transect. The total number of sampling points was $27(9 \times 3$ blocks $)$ in $100 \mathrm{~A}$ and $100 \mathrm{E}$ and $54(18 \times 3$ blocks) in 50A50E. Soil samples were air-dried and sieved at $4 \mathrm{~mm}$. Soil $\mathrm{pH}$ in $\mathrm{H}_{2} \mathrm{O}$ and $1 \mathrm{~mol} \cdot \mathrm{L}^{-1} \mathrm{KCl}$ (sample:liquid ratio, 1:5) were measured using a $\mathrm{S} 47$ SevenMulti TM (Mettler Toledo, Switzerland) after the suspensions were shaken for $30 \mathrm{~min}$ and equilibrated for one hour.

\section{Particulate organic matter fractionation}

Since the studied soils are sandy and contain low Fe oxide (Mareschal et al. 2011), the physical fractionation of POM was done according to Epron et al. (2015), and was followed by decantation to separate organic from mineral material as follows: $20 \mathrm{~g}$ of air-dried soil (sieved $<4 \mathrm{~mm}$ ), 5 glass beads and $50 \mathrm{~mL}$ of distilled water were put in a $100-\mathrm{mL}$ plastic bottle, and shaken for $16 \mathrm{~h}$ at $20{ }^{\circ} \mathrm{C}$ in an end-over-end shaker at $40 \mathrm{rpm}$ (6 rotations.$\left.\min ^{-1}\right)$. The suspension was wet-sieved to separate the $4000-250,250-50$ and $0-50 \mu \mathrm{m}$ fractions. In the two 
larger fractions, the organic components were separated from the mineral fraction by decantation. The following fractions were obtained: coarse POM (cPOM, 4000$250 \mu \mathrm{m}$ ), fine POM (fPOM, 250-50 $\mu \mathrm{m}$ ), organo-mineral fraction (OMF, $<50 \mu \mathrm{m}$ ), and the coarse and fine mineral fractions (cMIN 4000-250 $\mu \mathrm{m}$ and fMIN, 250$50 \mu \mathrm{m})$. Of these, only cPOM, fPOM and OMF composed of organic material are considered in this study. All fractions were dried at $45^{\circ} \mathrm{C}$ for $72 \mathrm{~h}$ and weighed.

The mass percentage of $\mathrm{N}, \mathrm{C}$ and $\mathrm{S}$ concentrations in bulk soil, cPOM, FPOM, and OMF fractions were determined simultaneously using a Macro VARIO Cube Elemental Analyser (Germany). Available P in bulk soil, soil fractions and forest floor litter were determined by resin extraction. Two anion-exchange resin strips (BDH\#551642S) each $20 \mathrm{~mm} \times 60 \mathrm{~mm}$ were added to $0.5 \mathrm{~g}$ (soil) or $0.1-0.2 \mathrm{~g}$ (POM fraction) and suspended in $30 \mathrm{ml}$ distilled water. Phosphate adsorbed by the anionexchange resin was recovered in $20 \mathrm{~mL}$ of $0.5 \mathrm{~mol} \cdot \mathrm{L}^{-1}$ $\mathrm{HCl}$ after shaking for $16 \mathrm{~h}\left(100 \mathrm{revs} \cdot \mathrm{min}^{-1}\right)$ according to the method of Tiessen and Moir (2008). Malachite reactive P was determined at $630 \mathrm{~nm}$ with a JENWAY 6305 Spectrophotometer (UK).

\section{Statistical analyses}

Statistical analyses were performed with $\mathrm{R}$ software version 3.2.4 ( $\mathrm{R}$ Core Team 2016). Similar analyses were performed to compare data of 7 years of the first rotation to 2 years of the second rotation (Koutika et al. 2017). The total number of samples in this study was 108, i.e., $27(9 \times 3$ blocks $)$ replicates were used for $100 \mathrm{~A}$ and $100 \mathrm{E}$ stands, and $54(18 \times 3$ blocks $)$ for the mixedspecies stands (50A50E). For the analysis at 5 years of the second rotation (R2Y5), a mixed-effect model (Bates et al. 2015) with blocks as random effects was used to estimate the effects of stand types (100A, 100E and $50 \mathrm{~A} 50 \mathrm{E})$ as fixed effect. For the analysis at the three dates, i.e., the end of the first 7-year rotation (R1Y7), 2 (R2Y2) and 5 years (R2Y5) of the second rotation, a mixed-effect model (Bates et al. 2015) with blocks as random effects was used to estimate the effects of stand types (100A, 100E and 50A50E) and time (R1Y7, R2Y2 and R2Y5) as fixed effects.

\section{Results}

\section{Water and $\mathrm{KCl} \mathrm{pH}$}

At year 5 of the second rotation (R2Y5), both afforested stands with acacia, i.e., 100A and 50A50E had significantly lower soil $\mathrm{pH}\left(\mathrm{H}_{2} \mathrm{O}\right)$ than pure eucalypt (100E) stands (4.2) (Table 1). There were no significant differences in $\mathrm{pH}-\mathrm{KCl}$ between stands. The difference between $\mathrm{pH}-\mathrm{H}_{2} \mathrm{O}$ and $\mathrm{pH}-\mathrm{KCl}$ i.e., delta $\mathrm{pH}(\Delta \mathrm{pH})$ was significantly higher in the $100 \mathrm{E}$ stand (Table 1). Along rotations, i.e., from the end of the first 7-year-rotation (R1Y7) to year 2 (R2Y2) and 5 (R2Y5) of the second rotation, soil $\mathrm{pH}-\mathrm{H}_{2} \mathrm{O}$ was higher in $100 \mathrm{E}$, and lower in $100 \mathrm{~A}$ at R1Y7 and R2Y2. There was no significant difference between $\mathrm{pH}-\mathrm{KCl}$ in the three stands along the rotations, except for the significantly lower value in 50A50E relative to others at R2Y2 (Table 1). A higher change in soil $\mathrm{pH}$ was found in $100 \mathrm{E}$ and a lower change in soil pH was found in 100A at both R1Y7 and R2Y5, while no difference between stands was observed at R2Y2 (Table 1).

\section{Concentrations and quality of POM at year 5 of the second rotation (R2Y5) Weight of POM and organo-mineral fractions}

There was no difference in the weight of coarse (cPOM, $4000-250 \mu \mathrm{m})$, fine $(250-50 \mu \mathrm{m}) \mathrm{POM}$ or organo-mineral $(<50 \mu \mathrm{m})$ fractions based on $20 \mathrm{~g}$ fractionated soil between all studied stands (Table 2). This tendency remained when the weight was estimated in gram per $\mathrm{kg}$ of soil (Table 2).

\section{$N, C$, and $S$ concentrations and $P$ availability in bulk, POM and organo-mineral fractions}

cPOM $(4000-250 \mu \mathrm{m})$ beneath $100 \mathrm{~A}$ had significantly higher $\mathrm{N}$ concentration (1.71\%) than in either 50A50E and 100E stands (Fig. 1a). As for the bulk soil, no difference was found between stand types for $\mathrm{PPOM}$ and OMF. There was no difference in $\mathrm{C}$ concentration between stand types for bulk soil and all fractions (Fig. 1b). Sulphur concentration was significantly lower in the cPOM beneath 50A50E (0.17\%) relative to $100 \mathrm{~A}(0.21 \%)$ stands, while there was no difference between bulk soil and fractions (Fig. 1c). The significantly lower $\mathrm{P}$ availability was still observed in the cPOM in 50A50E (4.6

Table 1 Soil pH change along rotations from the end of the first 7-year-rotation (R1Y7), to year 2 of the second rotation (R2Y2) and 5 of the second rotation (R2Y5)

\begin{tabular}{|c|c|c|c|c|c|c|c|c|c|}
\hline & \multicolumn{3}{|l|}{ R1Y7 } & \multicolumn{3}{|l|}{$\mathrm{R} 2 \mathrm{Y} 2$} & \multicolumn{3}{|l|}{$\mathrm{R} 2 \mathrm{Y} 5$} \\
\hline & $100 \mathrm{~A}$ & 50A50E & $100 E$ & $100 \mathrm{~A}$ & 50A50E & $100 E$ & $100 \mathrm{~A}$ & 50A50E & $100 \mathrm{E}$ \\
\hline $\mathrm{pH}-\mathrm{H}_{2} \mathrm{O}$ & $4.2( \pm 0.03) c$ & $4.4( \pm 0.02) b$ & $4.5( \pm 0.04) \mathrm{a}$ & $4.4( \pm 0.02) a$ & $4.3( \pm 0.03) a$ & $4.4( \pm 0.03) a$ & $3.9( \pm 0.05) b$ & $4.0( \pm 0.03) b$ & $4.2( \pm 0.04) \mathrm{a}$ \\
\hline $\mathrm{pH}-\mathrm{KCl}$ & $3.5( \pm 0.02) \mathrm{a}$ & $3.5( \pm 0.02) a$ & $3.5( \pm 0.03) \mathrm{a}$ & $3.3( \pm 0.02) a$ & $3.2( \pm 0.02) b$ & $3.3( \pm 0.03) a$ & $3.5( \pm 0.02) a$ & $3.5( \pm 0.02) a$ & $3.5( \pm 0.04) \mathrm{a}$ \\
\hline Delta $\mathrm{pH}(\Delta \mathrm{pH})$ & $0.8( \pm 0.03) c$ & $0.9( \pm 0.01) b$ & $1.0( \pm 0.02) \mathrm{a}$ & $1.1( \pm 0.02) \mathrm{a}$ & $1.1( \pm 0.02) b$ & $1.1( \pm 0.03) \mathrm{a}$ & $0.4( \pm 0.06) a b$ & $0.5( \pm 0.03) b$ & $0.6( \pm 0.05) \mathrm{a}$ \\
\hline
\end{tabular}


Table 2 Weight of particulate organic matter (POM 4000-50 $\mu \mathrm{m}$ ) fractions at year 5 of the second rotation (R2Y5)

\begin{tabular}{llll}
\hline POM fraction weight /Stands & $100 \mathrm{~A}$ & $50 \mathrm{~A} 50 \mathrm{E}$ & $100 \mathrm{E}$ \\
\hline After fractionation of $20 \mathrm{~g}$ of soil: & & & $0.18( \pm 0.01) \mathrm{a}$ \\
CPOM & $0.14( \pm 0.01) \mathrm{a}$ & $0.39( \pm 0.02) \mathrm{a}$ & $0.19( \pm 0.03) \mathrm{a}$ \\
fPOM & $0.35( \pm 0.02) \mathrm{a}$ & $1.61( \pm 0.17) \mathrm{a}$ & $1.81( \pm 0.07) \mathrm{a}$ \\
OMF & $2.01( \pm 0.06) \mathrm{a}$ & & $9.03) \mathrm{a}$ \\
In g per kg of soil: & & $8.93( \pm 0.47) \mathrm{a}$ & $9.47( \pm 1.42) \mathrm{a}$ \\
CPOM & $6.87( \pm 0.52) \mathrm{a}$ & $19.53( \pm 0.28) \mathrm{a}$ & $19.77( \pm 1.42) \mathrm{a}$ \\
fPOM & $17.71( \pm 1.01) \mathrm{a}$ & $88.7( \pm 1.6) \mathrm{a}$ & $90.3( \pm 3.7) \mathrm{a}$ \\
OMF & $100.7( \pm 3.2) \mathrm{a}$ &
\end{tabular}

$100 \mathrm{~A}$ and $100 \mathrm{E}=$ pure acacia and eucalypt, respectively, while $50 \mathrm{~A} 50 \mathrm{E}=$ mixed-species $(50 \%$ acacia and $50 \%$ eucalypt) stands. cPOM = coarse POM (4000-250 $\mu \mathrm{m}), \mathrm{fPOM}=$ fine POM $(250-50 \mu \mathrm{m})$ and OMF $=$ organo-mineral fractions $(<50 \mu \mathrm{m})$. Different letters indicate significant differences at $P=0.05$ between stand types at R2Y5

$\mathrm{mg} \mathrm{P} \cdot \mathrm{kg}^{-1}$ ) relative to $100 \mathrm{E}$ and $100 \mathrm{~A}$ stands $(>6 \mathrm{mg}$ $\mathrm{P} \cdot \mathrm{kg}^{-1}$, Fig. 1d), and no difference was found elsewhere. $\mathrm{P}$ availability was extremely low at R2Y5 compared to other periods (Fig. 1).

\section{Weight and C concentration of forest floor litter}

The higher dry weights of forest coarse and fine litter were both found in 100A (414.7 and $214.5 \mathrm{~g}$, respectively) relative to the other two stand types $(<200$ and $160 \mathrm{~g}$, respectively, Fig. 2a). When the weight was expressed in gram per $\mathrm{m}^{2}$, the tendency remained; the significantly higher value for both coarse $\left(1.58 \mathrm{~g} \cdot \mathrm{m}^{-2}\right)$ and fine $\left(0.81 \mathrm{~g} \cdot \mathrm{m}^{-2}\right)$ forest floor litter were still found in 100A (Fig. 2b). There was no difference in the $\mathrm{N}$ and $\mathrm{S}$ concentrations and $\mathrm{P}$ availability in both coarse and fine forest floor litter in all studied stand types (Data not shown). C concentration in the coarse forest floor litter was significantly higher in the $100 \mathrm{E}$ stands (36.5\%), while the higher in fine forest floor was observed in 50A50E (38.7\%) (Fig. 2c).

SOM dynamics along rotations: from the end of the first 7-year-rotation (R1Y7) to year 2 (R2Y2) and 5 (R2Y2) of the second rotation

\section{$N$ and $C$ concentration in bulk soil and soil fractions}

Higher $\mathrm{N}$ concentration was found in bulk soil at year 2 of the second rotation (R2Y5) relative to year 7 of the first rotation (R1Y7) and year 2 of the second rotation (R2Y2) (Fig. 3a). Stands containing acacia had higher $\mathrm{N}$ concentrations, particularly in $\mathrm{cPOM}$ of the
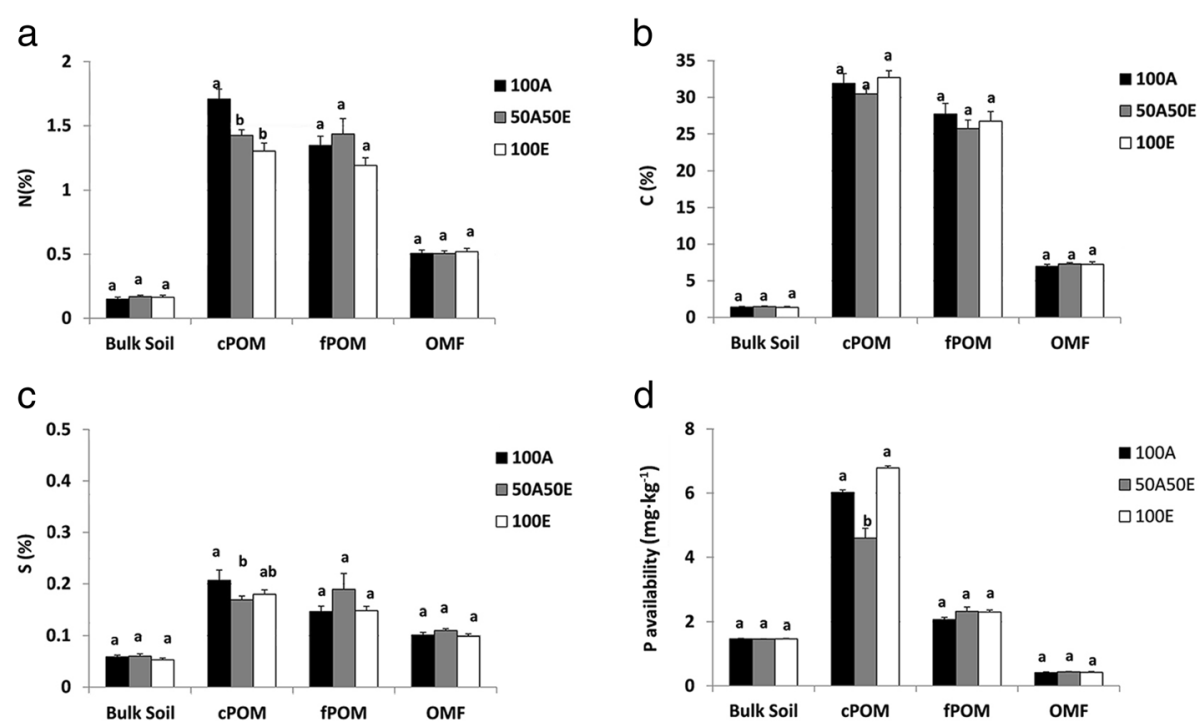

Fig. 1 Nitrogen (N) concentration (\%) (a), C (b), sulphur (c) and phosphorus availability (d) in the bulk soil and particulate organic matter (POM 4000-50 $\mu \mathrm{m}$ ) fractions at year 5 of the second rotation (R2Y5). 100A and 100E = pure acacia and eucalypt, respectively, while 50A50E $=$ mixedspecies (50\% acacia and 50\% eucalypt) stands. CPOM = coarse POM (4000-250 $\mu \mathrm{m}), \mathrm{PPOM}=$ fine POM (250-50 $\mu \mathrm{m})$ and OMF = organo-mineral fractions $(<50 \mu \mathrm{m})$. Vertical bars are the standard errors of three-block averages. Different letters indicate significant differences at $P=0.05$ between stand types at R2Y5 


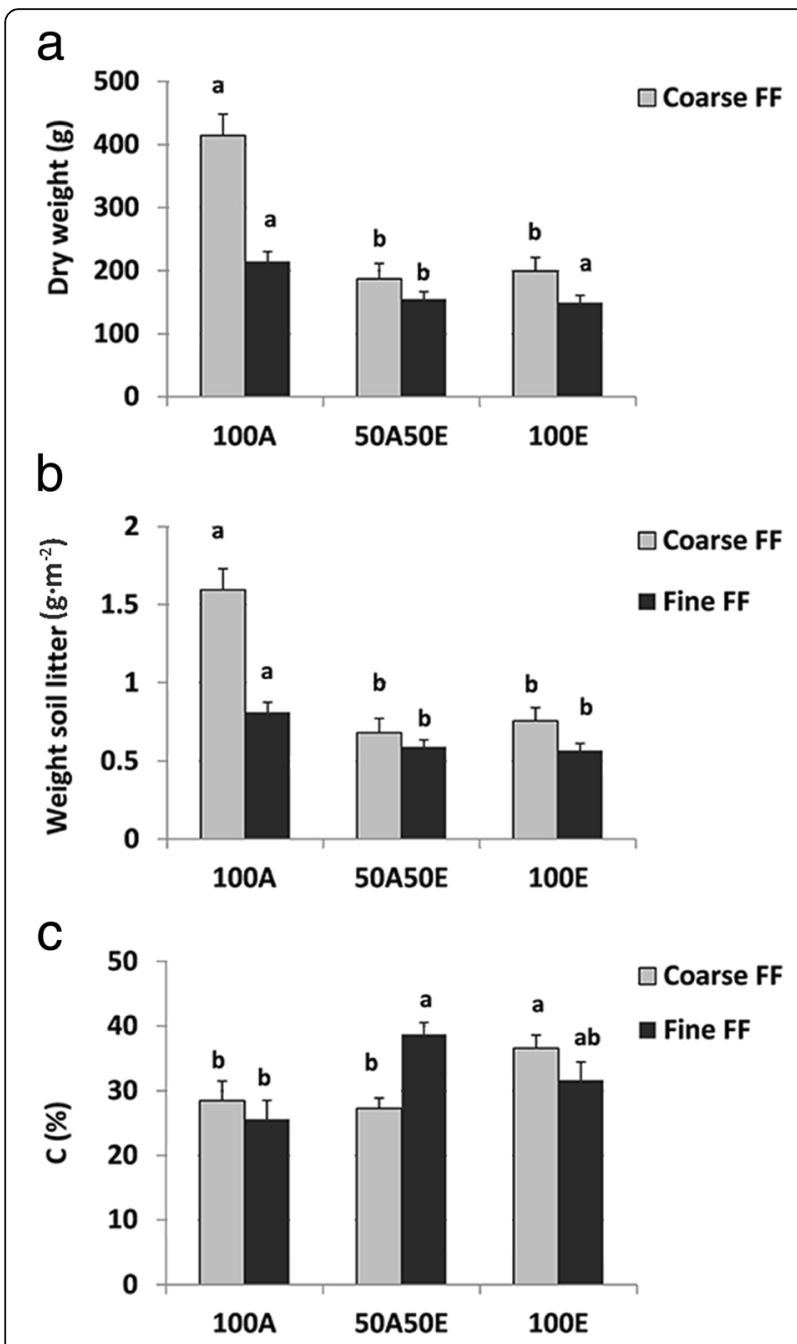

Fig. 2 Dry weight (g) (a), weight per $\mathrm{m}^{2}$ (b) and C concentration (\%) (c) in the coarse (coarse SL) and fine (Fine SL) forest floor at year 5 of the second rotation (R2Y5). 100A and 100E = pure acacia and eucalypt, respectively, while 50A50E $=$ mixed-species $(50 \%$ acacia and $50 \%$ eucalypt) stands. Vertical bars are the standard errors of threeblock averages. Different letters indicate significant differences at $P=0.05$ between stand types at R2Y5

pure acacia stands (100A) along rotations (Fig. 3b). For instance, higher $\mathrm{N}$ concentration was found in cPOM beneath $100 \mathrm{~A}$ at $\mathrm{R} 2 \mathrm{Y} 2$ relative to $\mathrm{R} 1 \mathrm{Y} 7$ and R2Y5. This tendency was less pronounced in $\mathrm{fPOM}$, except in $100 \mathrm{~A}$ at R2Y2 (Fig. 3c). Higher N concentration in OMF was observed at R2Y2 of all stands, while R2Y5 had lower values (Fig. 3d). C concentration in bulk soil beneath $100 \mathrm{~A}$ stand was significantly lower than $100 \mathrm{E}$ and 50A50E stands at R2Y2 (Fig. 4a). Higher C concentration was often observed in all stands at R2Y2 relative to R1Y7, with a more pronounced tendency to R2Y5 although at this stage, lower $C$ concentrations were found in all soil fractions (Figs. 4b, c \&d). Bulk soils had a low C to $\mathrm{N}$ ratios, ranging from 9.7 (100E) to $11.3(100 \mathrm{~A})$ at
R2Y5 (Table 3), as a consequence of relative high $\mathrm{N}$ concentration (Fig. 3a). The mass fraction of cPOM in the three stand types at R2Y2 was significantly higher relative to R1Y7 and R2Y5, while the highest values for fPOM were at R2Y5 (Table 3). Overall both $\mathrm{N}$ and $\mathrm{C}$ concentrations decreased (Table 4). Both $\mathrm{C}$ and $\mathrm{N}$ concentrations were much lower at R1Y7 and R2Y5 than at R2Y2. The decrease in $\mathrm{N}$ and $\mathrm{C}$ (cPOM), at R1Y7 was less than $20 \%$, compared with R2Y2 (Table 4). The higher values were observed at R2Y5 mainly in $\mathrm{PPOM}$ and ranged between $10 \%-35 \%$ for both $\mathrm{N}$ and $\mathrm{C}$ and $20 \%-35 \%$ for both $\mathrm{N}$ and $\mathrm{C}$ in OMF.

\section{Discussion}

SOM dynamics through CPOM

Even though there was no difference in mass of POM fractions between stands at R2Y5 in the current study (Table 2), $\mathrm{N}$ concentrations were higher in the $\mathrm{cPOM}$ $(4000-250 \mu \mathrm{m})$ beneath 100A (Fig. 1a), and coarse and fine forest floor necromass were higher (Figs. 2a \& b), but its $\mathrm{C}$ concentrations were both lower (Fig. 2c). Initially changes in POM $(4000-50 \mu \mathrm{m})$ status, one of the most active parts of SOM, occurred in its coarse (4000$250 \mu \mathrm{m}$ ) fraction, through its quality, i.e., concentrations in N, C, P availability, etc. (Koutika et al. 2001; Koutika et al. 2017; Koutika and Mareschal 2017), or/and quantity i.e., mass (Epron et al. 2015). In a study on reforestation of tropical pastures in Puerto Rico estimating SOM dynamics through turnover times of $\mathrm{C}$ in the bulk soil and in density fractions during 80 years, MarinSpiotta et al. (2009) identified the physically unprotected $\mathrm{POM}$ as the fraction most sensitive to land-use change. In another study in Central China, the effects of landuse change during afforestation of large uncultivated areas showed increased soil $\mathrm{C}$ and $\mathrm{N}$ storage, mainly in macroaggregates (> $2000 \mu \mathrm{m})$ (Dou et al. 2016).

The higher $\mathrm{N}$ concentration in $\mathrm{CPOM}$ and weight of coarse and fine forest floor litter in 100A observed in the current studies are in accordance with previous findings that the higher cumulative net production of mineral $\mathrm{N}$ over the two first years of the second rotation in 100A (343 kg.ha $\left.{ }^{-1}\right)$ relative to 100E $\left(189 \mathrm{~kg} \cdot \mathrm{ha}^{-1}\right)$ (Tchichelle et al. 2017). Even though P may be retranslocated along the tree growth period (Inagaki et al. 2011), the enhanced SOM dynamics in the pure acacia (100A) stands in the current study may be also linked to the high requirement of NFS for available P (Binkley 1992). This high requirement for $\mathrm{P}$ probably decreased the resin available $P$ in the $0.15 \mathrm{~m}$ in $100 \mathrm{~A}$ relative $100 \mathrm{E}$ stands and soil readily available inorganic $\mathrm{P}$ (resin and $\mathrm{Pi}-\mathrm{HCO}_{3}$ ), i.e., 1.7 vs $2.17 \mathrm{mg} \cdot \mathrm{kg}^{-1}$ for $\mathrm{Pi}-\mathrm{HCO}_{3}$ previously reported at year 2 of the second rotation i.e., R2Y2 (Koutika et al. 2016), but also in CPOM of the mixedspecies (50A50E) stands at R2Y2 (Fig. 1d). Even though 

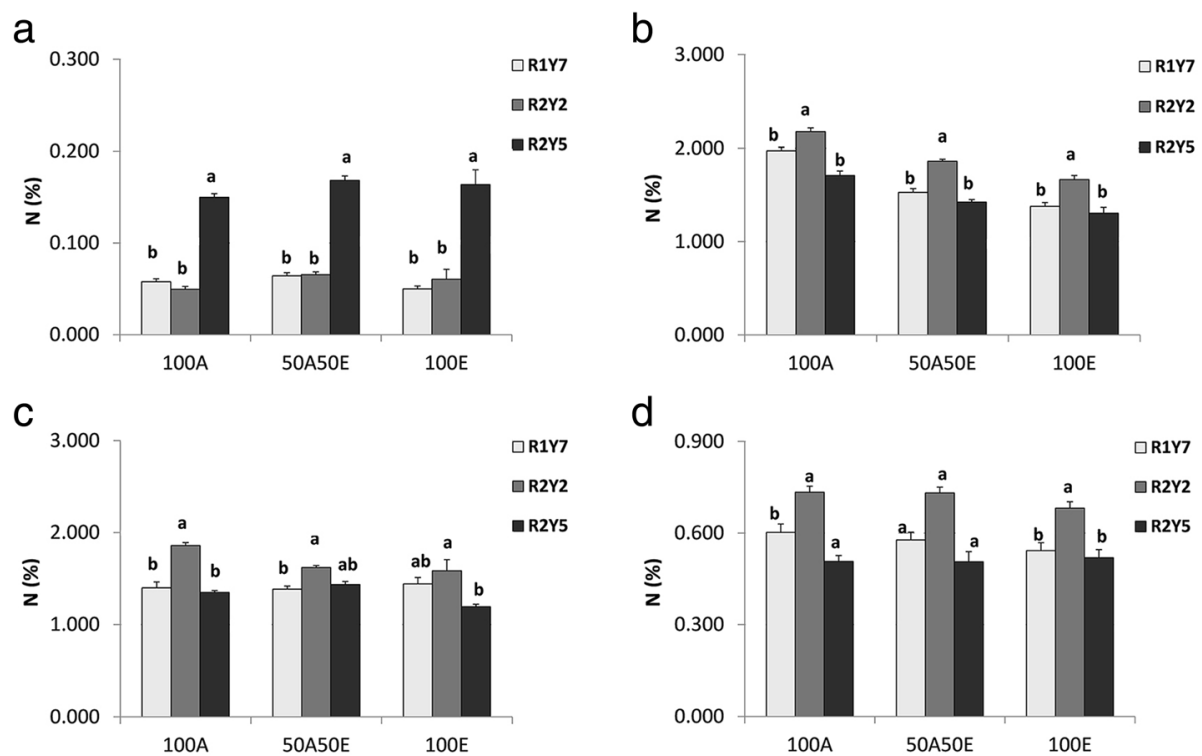

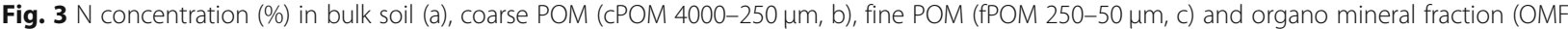
0-50 $\mu \mathrm{m}, \mathrm{d})$ along rotations. 100A and 100E = pure acacia and eucalypt, respectively, while 50A50E $=$ mixed-species $(50 \%$ acacia and $50 \%$ eucalypt) stands. R1Y7 = Year 7 of the first rotation; R2Y2 = Year 2 of the second rotation and R2Y5 = Year 5 of the second rotation. Vertical bars are the standard errors of three-block averages. Different letters indicate significant differences at $P=0.05$ between stand types at each rotation stage and along rotations
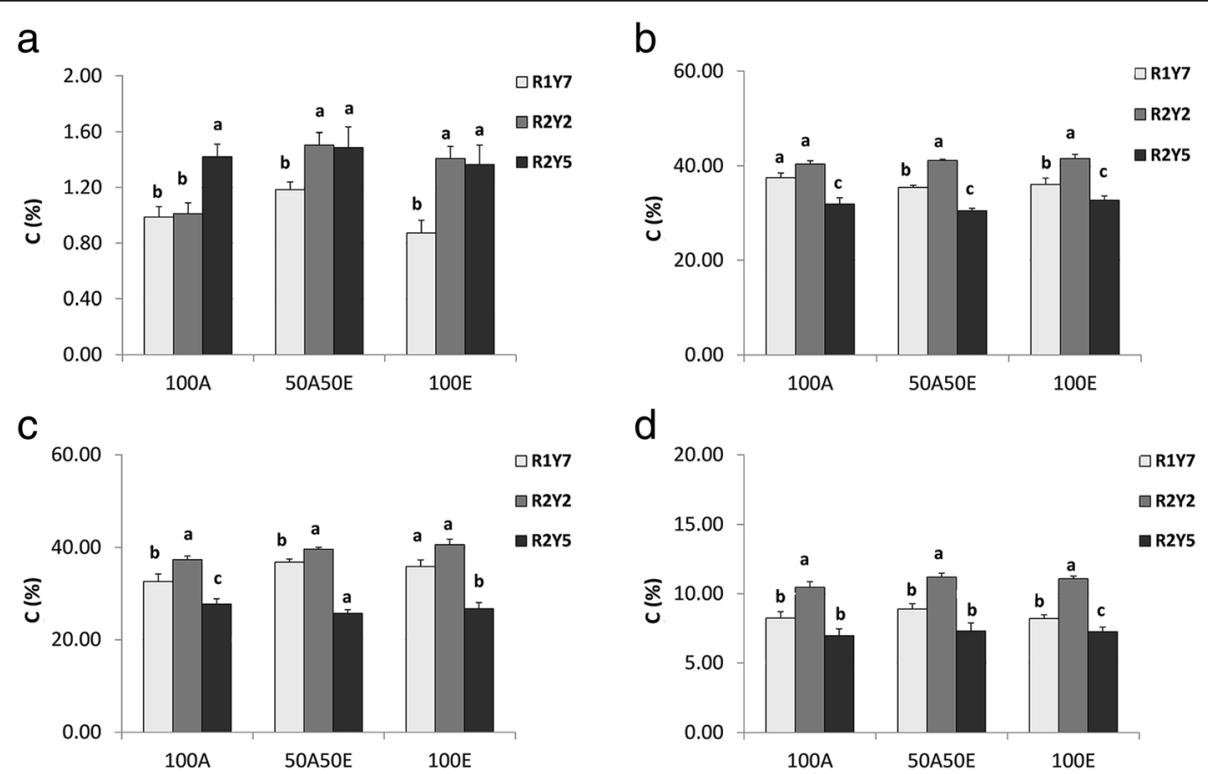

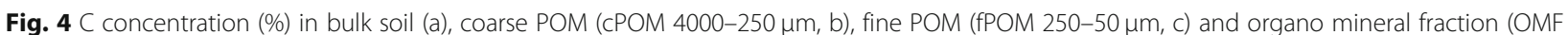
0-50 $\mu \mathrm{m}, \mathrm{d})$ along rotations. 100A and 100E = pure acacia and eucalypt, respectively, while 50A50E $=$ mixed-species $(50 \%$ acacia and $50 \%$ eucalypt) stands. R1Y7 = Year 7 of the first rotation; R2Y2 = Year 2 of the second rotation and R2Y $5=$ Year 5 of the second rotation. Vertical bars are the standard errors of three-block averages. Different letters indicate significant differences at $P=0.05$ between stand types at each rotation stage and along rotations 
Table 3 CN ratio of bulk soil and soil fractions (CPOM; $\mathrm{PPOM}$ and OMF) and mass of fractions along rotations from the end of the first 7-year-rotation (R1Y7), to year 2 of the second rotation (R2Y2) and 5 of the second rotation (R2Y5)

\begin{tabular}{|c|c|c|c|c|c|c|c|c|c|}
\hline \multirow[b]{2}{*}{ Soil/fractions } & \multicolumn{3}{|l|}{$\mathrm{R} 1 \mathrm{Y7}$} & \multicolumn{3}{|l|}{$\mathrm{R} 2 \mathrm{Y} 2$} & \multicolumn{3}{|l|}{ R2Y5 } \\
\hline & $100 \mathrm{~A}$ & 50A50E & $100 E$ & $100 \mathrm{~A}$ & 50A50E & $100 \mathrm{E}$ & $100 \mathrm{~A}$ & 50A50E & $100 \mathrm{E}$ \\
\hline CN bulk soil & $\begin{array}{l}16.9( \pm 0.054) \\
\mathrm{a}\end{array}$ & $\begin{array}{l}17.8( \pm 0.48) \\
a\end{array}$ & $\begin{array}{l}17.1( \pm 0.51) \\
\mathrm{a}\end{array}$ & $\begin{array}{l}20.2( \pm 0.43) \\
a\end{array}$ & $\begin{array}{l}22.7( \pm 0.19) \\
b\end{array}$ & $\begin{array}{l}25.0( \pm 0.27) \\
a\end{array}$ & $\begin{array}{l}11.3( \pm 0.90) \\
b\end{array}$ & $\begin{array}{l}10.4( \pm 0.66) \\
b\end{array}$ & $\begin{array}{l}9.7( \pm 0.95) \\
a\end{array}$ \\
\hline CN CPOM & $\begin{array}{l}19.4( \pm 0.056) \\
\mathrm{a}\end{array}$ & $\begin{array}{l}23.9( \pm 0.68) \\
b\end{array}$ & $\begin{array}{l}26.5( \pm 0.91) \\
c\end{array}$ & $\begin{array}{l}18.6( \pm 0.16) \\
a\end{array}$ & $\begin{array}{l}22.2( \pm 0.19) \\
b\end{array}$ & $\begin{array}{l}25.0( \pm 0.27) \\
a\end{array}$ & $\begin{array}{l}18.8( \pm 0.36) \\
b\end{array}$ & $\begin{array}{l}21.5( \pm 0.27) \\
b\end{array}$ & $\begin{array}{l}25.9( \pm 0.88) \\
a\end{array}$ \\
\hline CN fPOM & $\begin{array}{l}24.1( \pm 1.68) \\
a\end{array}$ & $\begin{array}{l}27.1( \pm 0.72) \\
a b\end{array}$ & $\begin{array}{l}25.4( \pm 0.81) \\
a\end{array}$ & $\begin{array}{l}20.2( \pm 0.32) \\
a\end{array}$ & $\begin{array}{l}24.7( \pm 0.37) \\
b\end{array}$ & $\begin{array}{l}25.7( \pm 0.41) \\
a\end{array}$ & $\begin{array}{l}20.8( \pm 0.60) \\
b\end{array}$ & $\begin{array}{l}20.3( \pm 0.77) \\
b\end{array}$ & $\begin{array}{l}22.8( \pm 0.79) \\
a\end{array}$ \\
\hline CN OMF & $\begin{array}{l}13.6( \pm 0.034) \\
a\end{array}$ & $\begin{array}{l}15.3( \pm 0.27) \\
b\end{array}$ & $\begin{array}{l}14.9( \pm 0.43) \\
b\end{array}$ & $\begin{array}{l}14.3( \pm 0.17) \\
a\end{array}$ & $\begin{array}{l}15.3( \pm 0.18) \\
b\end{array}$ & $\begin{array}{l}16.2( \pm 0.30) \\
a\end{array}$ & $\begin{array}{l}14.1( \pm 0.33) \\
b\end{array}$ & $\begin{array}{l}14.9( \pm 0.32) \\
b\end{array}$ & $\begin{array}{l}14.2( \pm 0.31) \\
a\end{array}$ \\
\hline $\begin{array}{l}\text { CPOM (fraction } \\
\text { per g) }\end{array}$ & $\begin{array}{l}0.11( \pm 0.001) \\
a\end{array}$ & $\begin{array}{l}0.15( \pm 0.02) \\
\mathrm{b}\end{array}$ & $\begin{array}{l}0.10( \pm 0.01) \\
\mathrm{a}\end{array}$ & $\begin{array}{l}0.41( \pm 0.03) \\
a\end{array}$ & $\begin{array}{l}0.49( \pm 0.03) \\
b\end{array}$ & $\begin{array}{l}0.34( \pm 0.03) \\
a\end{array}$ & $\begin{array}{l}0.14( \pm 0.01) \\
b\end{array}$ & $\begin{array}{l}0.18( \pm 0.01) \\
b\end{array}$ & $\begin{array}{l}0.19( \pm 0.03) \\
a\end{array}$ \\
\hline $\begin{array}{l}\text { fPOM (fraction } \\
\text { per g) }\end{array}$ & $\begin{array}{l}0.20( \pm 0.002) \\
b\end{array}$ & $\begin{array}{l}0.19( \pm 0.02) \\
b\end{array}$ & $\begin{array}{l}0.17( \pm 0.02) \\
a\end{array}$ & $\begin{array}{l}0.23( \pm 0.01) \\
a\end{array}$ & $\begin{array}{l}0.30( \pm 0.01) \\
b\end{array}$ & $\begin{array}{l}0.28( \pm 0.02) \\
a\end{array}$ & $\begin{array}{l}0.35( \pm 0.02) \\
b\end{array}$ & $\begin{array}{l}0.39( \pm 0.02) \\
b\end{array}$ & $\begin{array}{l}0.40( \pm 0.03) \\
a\end{array}$ \\
\hline $\begin{array}{l}\text { OMF (fraction } \\
\text { per g) }\end{array}$ & $\begin{array}{l}1.91( \pm 0.005) \\
b\end{array}$ & $\begin{array}{l}1.86( \pm 0.04) \\
a\end{array}$ & $\begin{array}{l}1.83( \pm 0.07) \\
\mathrm{a}\end{array}$ & $\begin{array}{l}1.47( \pm 0.03) \\
a\end{array}$ & $\begin{array}{l}1.64( \pm 0.03) \\
b\end{array}$ & $\begin{array}{l}1.56( \pm 0.05) \\
a\end{array}$ & $\begin{array}{l}2.01( \pm 0.06) \\
b\end{array}$ & $\begin{array}{l}1.77( \pm 0.03) \\
b\end{array}$ & $\begin{array}{l}1.81( \pm 0.07) \\
a\end{array}$ \\
\hline
\end{tabular}

$100 \mathrm{~A}$ and $100 \mathrm{E}=$ pure acacia and eucalypt, respectively, while 50A50E = mixed-species $(50 \%$ acacia and $50 \%$ eucalypt $)$ stands. cPOM = coarse POM $(4000-250 \mu \mathrm{m})$, $\mathrm{fPOM}=$ fine POM $(250-50 \mu \mathrm{m})$ and $\mathrm{OMF}=$ organo-mineral fractions $(<50 \mu \mathrm{m})$. Different letters indicate significant differences at $P=0.05$ between stand types at each rotation stage and along rotations

there was no difference in $\mathrm{C}$ concentration of bulk soil and POM fractions between the three studied stands, the lower $\mathrm{C}$ concentration in coarse and fine litter beneath pure acacia may be explainable by larger $C$ net ecosystem productivity in eucalypt stands relative to acacia stands. For example, in Guangdong Province of southern China, Chen et al. (2011) found net ecosystem productivity of $1960 \pm 178 \mathrm{~g} \mathrm{C} \cdot \mathrm{m}^{-2} \cdot \mathrm{yr}^{-1}$ for E. urophylla but $330 \pm 76 \mathrm{~g} \mathrm{C} \cdot \mathrm{m}^{-2} \cdot \mathrm{yr}^{-1}$ for $A$. crassicarpa.

Contrary to our findings, Pereira et al. (2018) found differences in mass of POM fractions at the juvenile stage of a first rotation (27 to 39th months of the trees). SOM dynamics depends on different factors including soil texture, climate and relief; for instance, soils at Tchissoko in the Congolese coastal plains are Ferralic arenosols (with a ratio of clay: silk: sand of 3:6:91), while those at Itatinga in Brazil are Ferralsols (with a ratio of clay: silk: sand of 13:3:84). All differences between the two sites, including climate and relief, have been well documented in Epron et al. (2013), and led to a positive effect of growing eucalypt with acacia on stand wood production at Tchissoko but not at Itatinga. In the same line, Voigtlaender et al. (2012) did not find any differences in $\mathrm{N}$ and $\mathrm{C}$ stocks beneath the pure acacia (100A), eucalypt (100E) and mixed-species (50A50E) stands in the $0-15 \mathrm{~cm}$ soil layer after 6 years of plantation at Itatinga. Koutika et al. (2014) reported an increase in both $\mathrm{C}$ and $\mathrm{N}$ stocks in the $0-25 \mathrm{~cm}$ beneath $50 \mathrm{~A} 50 \mathrm{E}$ relative to $100 \mathrm{E}$ after 7 years of plantation in the Congolese coastal plains.

Enhanced SOM dynamics inferred by cPOM status were also highlighted by the lower concentration in $\mathrm{S}$ and available $\mathrm{P}$ in the 50A50E relative to $100 \mathrm{~A}$ and $100 \mathrm{E}$ stands at R2Y5 (Fig. 1c \& d). Besides, the common high requirement in available $\mathrm{P}$ for the symbiotic fixation of atmospheric $\mathrm{N}_{2}$ by NFS (Binkley 1992), changes occurring in 50A50E stands are probably due to enhanced bacterial community composition (Pereira et al. 2017). This may be due probably to high biomass wood production previously observed by Epron et al. (2013) in mixed-species stands of the plantation established in the Congolese coastal plains. In addition to above benefits in the 50A50E stands, an increase in bulk soil $\mathrm{N}$ and $\mathrm{C}$ stocks down to $0.25 \mathrm{~m}$ in $50 \mathrm{~A} 50 \mathrm{E}$ have been also reported at the end of the first 7 years in the Congolese coastal plains, as mentioned in the previous section (Koutika et al. 2014).

High soil N contents can enhance SOC accretion due to increases in both below- and aboveground biomass and forest growth (Binkley 1992; Epron et al. 2013; Fornara et al. 2013). In addition to the effect of $\mathrm{N}$ on SOM quantity, N-fixing trees might also impact on SOM dynamics due to biological changes stimulated by the input of N-rich litter (Binkley 2005) or enhanced bacterial community composition or changed in microbial indicators (Pereira et al. 2017, 2018). In the Congolese coastal plains, the faster cycling of soil $\mathrm{N}$ beneath stands containing acacia relative to eucalypt has been already reported at the end of 7 year-first rotation (R1Y7) by the $30 \%$ and $10 \%$ higher $\mathrm{N}$ concentration in $\mathrm{CPOM}$ in $100 \mathrm{~A}$ $\left(19.7 \pm 0.8 \mathrm{~g} \cdot \mathrm{kg}^{-1}\right)$ and $50 \mathrm{~A} 50 \mathrm{E}\left(15.3 \pm 0.4 \mathrm{~g} \cdot \mathrm{kg}^{-1}\right)$, relative to eucalypt $\left(13.8 \pm 0.5 \mathrm{~g} \cdot \mathrm{kg}^{-1}\right)$ (Koutika et al. 2017). This tendency remained at year 2 of the second rotation (R2Y5) with $\mathrm{N}$ concentration, which was still higher in cPOM in soil of stands containing acacia by $23 \%(21.7 \pm$ $0.4 \mathrm{~g} \cdot \mathrm{kg}^{-1}$ for $\left.100 \mathrm{~A}\right)$ and $11 \%\left(18.6 \pm 0.2 \mathrm{~g} \cdot \mathrm{kg}^{-1}\right.$ for 


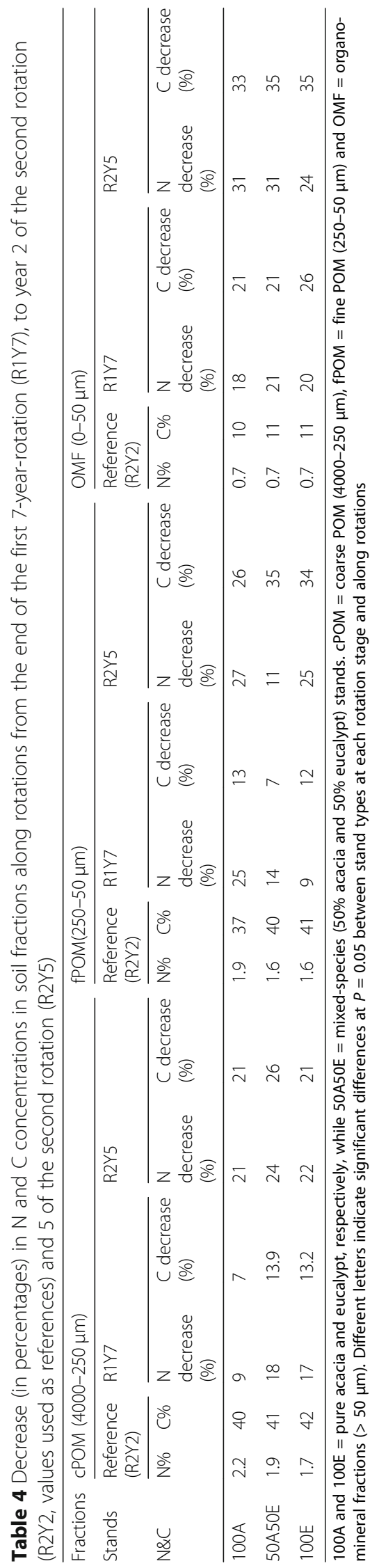


50A50E) relative to eucalypt $\left(16.7 \pm 0.2 \mathrm{~g} \cdot \mathrm{kg}^{-1}\right)$. This responds to our first question, i.e., SOM dynamics is enhanced through POM status and mainly its coarse fraction $(4000-250 \mu \mathrm{m})$, while available $\mathrm{P}$ decreased in cPOM beneath mixed-species stands at year 5 of the second rotation (R2Y5).

The link between $\mathrm{N}$ dynamics and $\mathrm{C}$ sequestration depends on several factors such as soil texture, water availability and $\mathrm{pH}$ and the importance of $\mathrm{N}$ in $\mathrm{C}$ sequestration processes and has been highlighted in several studies (Binkley 2005; Lal 2014; Li et al. 2012). The decrease in $\mathrm{C}$ concentration of POM fractions and OMF noticed at R2Y5 relative to the younger stage of rotation (R2Y2) i.e., between $20 \%-26 \%$ for cPOM, $25 \%-$ $35 \%$ for $\mathrm{PPOM}$ and $20 \%-35 \%$ for OMF may probably be due to an enhanced $\mathrm{C}$ mineralisation and decreased soil $\mathrm{pH}$ values (Table 1), involved by the high input of new organic residues along rotations, i.e., with the age of rotation. Studies conducted in the monoculture eucalypt plantations located in the Congolese coastal plains have shown that the input of labile substrate does alter the microbial community composition, potential metabolic activities, and the SOC pools utilisation (Derrien et al. 2014). Overall $\mathrm{N}$ and $\mathrm{C}$ dynamics in bulk soil and fractions is, therefore, showing an enhanced SOM i.e., $\mathrm{N}$ and $\mathrm{C}$ mineralization along rotations i.e., from R1Y7 to R2Y2 and R2Y5. For instance, when N dynamics is evaluated only through bulk soil, a higher $\mathrm{N}$ concentration was found at R2Y5 (Fig. 3a) along with very low $\mathrm{CN}$ ratio of bulk soil varied between 9.7 (100E) and 11.3 (100A) (Table 3), unusual in these soils. However, through POM dynamics, i.e., $\mathrm{N}$ and $\mathrm{C}$ concentrations in POM fractions, it appears that both $\mathrm{N}$ and $\mathrm{C}$ mineralization is enhanced with the age and length of rotation. This may reveal that introducing acacia in eucalypt plantations did involve $\mathrm{N}$ and $\mathrm{C}$ accretion in soil and POM fractions at the end of the first rotation (R1Y7) and at year 2 of the second rotation (R2Y2) as reported previously (Koutika et al. 2014; Koutika et al. 2017). However, the impact of edaphic factors and climate (sandy soil, high temperature and atmospheric humidity) in the Congolese coastal plains and the effects of new organic residues rich in $\mathrm{N}$ enhanced SOM dynamics i.e., mineralization of both $\mathrm{N}$ and $\mathrm{C}$, especially $\mathrm{C}$ (Table 4), but also decreased soil $\mathrm{pH}$ values (Table 1). Even though higher soil $\mathrm{N}$ availability usually permits $\mathrm{C}$ accretion and tends to reduce $\mathrm{C}$ loss and potentially contributes to climate change mitigation (Binkley 1992; Fornara et al. 2013), high N status at R2Y5 (Fig. 3a) did involve higher C concentration beneath $100 \mathrm{~A}$ relative to other periods (Fig. 4a). Previous studies in the area reported that SOM decomposition may be enhanced due to climate and edaphic factors, but also to newly add organic residues (d'Annunzio et al. 2008; Epron et al. 2013; Derrien et al. 2014). This also shows that changes in POM dynamics and soil $\mathrm{pH}$ along rotations, i.e., from R1Y7 to R2Y2 and R2Y5, have been affected by the high amounts of litterfall, forest floor and harvest residue left after the first harvest and accumulated along the second rotation, and responded to the third question of our paper.

Even though $\mathrm{N}$ and $\mathrm{C}$ increased in the mixed-species stands at the end of the first 7-years of rotation (R1Y7) and in 100A stands at year 2 of the second rotation (R2Y2) relative to 100E, $\mathrm{N}$ and $\mathrm{C}$ accretion appeared to have reached a threshold at R2Y5. SOM dynamics in the mixed-species plantations may therefore also be limited by the potential low SOM saturation of these sandy soils (Hassink 1997; Marin-Spiotta et al. 2009; Epron et al. 2015). Enhanced $N$ and $C$ mineralization along rotations with increasing age suggests that the ecosystem is fragile and both $\mathrm{N}$ and $\mathrm{C}$ accretion have a limit, reducing the potential beneficial effect of the practice on both soil fertility improvement and climate change mitigation, and responds to the fourth and fifth question of this paper. Soil acidification has been observed along rotations through a decrease in soil $\mathrm{pH} \mathrm{H}_{2} \mathrm{O}$ values in stands containing acacia relative to pure eucalypt counterparts (Table 1), while $\mathrm{P}$ availability reached a very low level never previously recorded in these soils. These findings are in accordance with previous studies worldwide showing that soil acidification or a decrease in available $P$ occurs when NFS fixing atmospheric $\mathrm{N}_{2}$ are introduced (Binkley 1992; Binkley 2005; Inagaki et al. 2011; Koutika et al. 2014)

\section{Conclusions}

Even when changes occurring in SOM quality were not yet detectable in the bulk soil, they could be observed through changes in POM status, especially its coarse fraction $(4000-250 \mu \mathrm{m})$ in stands containing acacia (100A and 50A50E). This has been shown by higher $\mathrm{N}$ concentration in the pure acacia (100A) or the lower $\mathrm{S}$ concentration and $\mathrm{P}$ availability in the mixed-species (50A50E), probably due to an enhanced both organic residues and mineralisation, decline in soil $\mathrm{pH}$ values and shift in microbial community composition and microbial indicators. SOM mineralisation was enhanced, while soil $\mathrm{pH}$ and $\mathrm{P}$ availability decreased with the age of stand, i.e., the length of rotation. This indicates an ecosystem containing more labile SOM, even though $\mathrm{N}$ and $\mathrm{C}$ accretion was noticed at the end of 7 years of the first rotation, and shows the importance of evaluating SOM quality, soil $\mathrm{pH}$ and $\mathrm{P}$ availability over a long period. The challenge of this study was to show that the introducing acacia in eucalypt plantations on the sandy and nutrient-poor soils involved soil $\mathrm{N}$ and $\mathrm{C}$ accretion and 
an increased potential of ecosystem to mitigate climate change. However these benefits may be limited in the long-term. This may be due to climate, edaphic factors, and the effects of new organic residues rich in $\mathrm{N}$ on SOM dynamics and soil $\mathrm{pH}$, diminishing the benefits of this practice on the ecosystem, and even threaten its equilibrium in a longer period, since after 12 years the ecosystem seems to contain more labile SOM and more acidic soils than after short time (7 years).

\section{Abbreviations}

100A: pure acacia or 100\% acacia; 100E: pure eucalypt or 100\% eucalypt; 50A50E: 50\% acacia and 50\% eucalypt or half acacia and half eucalypt; C: carbon; CPOM: coarse particulate organic matter; $\mathrm{PPOM}$ : fine particulate organic matter; N: nitrogen; NFS: nitrogen fixing species; OMF: organomineral fraction; P: phosphorus; POM: particulate organic matter; R1Y7: year 7 of the first rotation; R2Y2: year 2 of the second rotation; R2Y5: year 5 of the second rotation; SOM: soil organic matter

\section{Acknowledgements}

All who contributed towards the article who does not meet the criteria for authorship including anyone who provided professional writing services or materials have acknowledged.

The authors thank Professor Daniel Epron (Université de Lorraine) for the statistical analyses, staffs of CRDPI, Pointe-Noire, Republic of the Congo (JC Mazoumbou, T. Matsoumbou, B. Tchicaya, A. Nzoulou, E. Banguissa, A. Diamesso, A. Dzomambou, A. Kinana), for their contribution during the establishment of the experimental trial, and sampling of forest floor and soil and Professor Lindsey Norgrove (Bern University of Applied Sciences, School of Agricultural, Forest and Food Sciences) for editing the final version. The trial has been established and funded by the project Ecological Intensification of Plantation Forest Ecosystems i.e., R1Y7 and R2Y5 (Intens\&fix, agencenationalerecherche, France /Projet-ANR-10-STRA-0004). Soil chemical analyses (R2Y5) have been funded by ENEA Research Center, Rome Italy. This study was supported by the TWAS -ENEA Research Training Fellowships Programme to Lydie-Stella Koutika. Authors greatly acknowledge the ENEA Biotechnologies and Agroindustry Division for its support and administrative tasks.

\section{Authors' contributions}

LSK planned the project, made P analyses and wrote the first draft and contributed to the final stage; SN made POM fractionation; LC made soil analyses (C, N and S); AB contributed to the planning of the soil analyses, provided funds for soil chemical analyses, supervised the TWAS-ENEA International Research Fellowship and provided comments and recommendations for the final version. All authors read and approved the final manuscript.

\section{Authors' information}

LSK is a soil scientist at Research Centre on the Durability and the Productivity of Industrial Plantations (CRDPI), Pointe-Noire, Congo. She works on soil organic matter (both $\mathrm{C}$ and $\mathrm{N}$ ) and phosphorus dynamics in different ecosystems and currently in the mixed-species of eucalyptus and Acacia mangium plantations established in the Congolese coastal plains. She is a member of the scientific and technical committee of the Initiative ' 4 per 1000' Soils for Food Security and Climate (www.4per1000.org).

$\mathrm{SN}$ is a technician at Research Centre on the Durability and the Productivity of Industrial Plantations (CRDPI), Pointe-Noire, Congo.

LC is an engineering scientist and project manager at ENEA (Italian National Agency for New Technologies, Energy and Sustainable Economic Development) Casaccia Research Centre, Rome, Italy. He is involved in development of plastic recycling processes. Further, he is also skilled in various chemical analytical techniques applied to solid waste characterization.

$A B$ is the Head of the Laboratory for AgriFood Sustainability, Quality and Safety, Biotechnologies and Agroindustry Division, Department for Sustainability, ENEA Casaccia Research Centre, Rome, Italy. She is Professor of AgroFood Microbiology, Master's Degree in Food Science and Human Nutrition, University Campus Bio-Medico of Rome, Italy, and coordinator and principal investigator of international and national research projects and Management Committee
Substitute Member for Italy, Cost Action FP1305: Linking belowground biodiversity and ecosystem function in European Forests (Biolink).

\section{Funding}

LSK was supported by a TWAS-ENEA Research Training Fellowship

Programme. The funders had no role in study design, data collection and

analysis, decision to publish, or preparation of the manuscript.

\section{Availability of data and materials}

Not applicable. Journal style has been followed and dataset identifiers including DOls have been expressed as full URLS.

Ethics approval and consent to participate

Not applicable.

\section{Consent for publication}

Not applicable.

\section{Competing interests}

The authors declare that they have no competing interests.

\section{Author details}

${ }^{1}$ Research Center on the Durability and the Productivity of Industrial Plantations (CRDPI), B.P. 1291 Pointe-Noire, Republic of the Congo. ${ }^{2}$ Department for Sustainability, Biotechnologies and Agroindustry Division, Laboratory for AgriFood Sustainability, Quality and Safety, Italian National Agency for New Technologies, Energy and Sustainable Economic Development, ENEA, Casaccia Research Centre, 00123 Rome, Italy. ${ }^{3}$ Department for Sustainability, Division Resource Efficiency, Laboratory Technologies for the Reuse, Recycling, Recovery and valorisation of Waste and Materials, Italian National Agency for New Technologies, Energy and Sustainable Economic Development, ENEA, Casaccia Research Centre, 00123 Rome, Italy.

Received: 3 April 2019 Accepted: 14 August 2019

Published online: 04 September 2019

\section{References}

Bates D, Machler M, Bolker B, Walker S (2015) Fitting linear mixed-effects models using Ime4. J Stat Softw 67(1):1-48. https://doi.org/10.18637/jss.v067.i01

Bauters M, Ampoorter E, Huygens D, Kearsley E, De Haulleville T, Sellan G, Verbeeck H, Boeckx P, Verheyen K (2015) Functional identity explains carbon sequestration in a 77-year-old experimental tropical plantation. Ecosphere 6(10):198. https://doi.org/10.1890/ES15-00342.1

Bernhard-Reversat F (1993) Dynamics of litter and organic matter at the soil-litter interface of fast-growing tree plantations on sandy ferrallitic soils (Congo). Acta Ecol 14(2):179-195

Binkley D (1992) Mixtures of $\mathrm{N}_{2}$-fixing and non- $\mathrm{N}_{2}$-fixing tree species. In: Cannell MGR, Malcom DC (eds) The ecology of mixed-species stands of trees. Blackwell Scientific Publications, Oxford

Binkley D (2005) How nitrogen-fixing trees change soil carbon. In: Binkley D, Menyailo $O$ (eds) Tree species effects on soils: implications for global change. NATO Science Series, Kluwer Academic Publishers, Dordrecht, pp 155-164

Bouillet JP, Laclau JP, Gonçalves JLM, Voigtlaender M, Gava JL, Leite FP, Hakamada R, Mareschal L, Mabiala A, Tardy F, Levillain J, Deleporte P, Epron D, Nouvellon Y (2013) Eucalyptus and Acacia tree growth over entire rotation in single- and mixed-species plantations across five sites in Brazil and Congo. For Ecol Manag 301:89-101

Cambardella CA, Elliot ET (1992) Particulate soil organic matter changes across a grassland cultivation sequence. Soil Sci Soc Am J 56:777-783

Chen D, Zhang C, Wu J, Zhou L, Lin Y, Fu S (2011) Subtropical plantations are large carbon sinks: evidence from two monoculture plantations in South China. Agric For Meteorol 151:1214-1225

Corbeels M, McMurtrie RE, Pepper DA, Mendham DS, Grove TS, O'Connell AM (2005) Long-term changes in productivity of eucalypt plantations under different harvest residue and nitrogen management practices: a modelling analysis. For Ecol Manag 217:1-18

d'Annunzio R, Conche S, Landais D, Saint-Andre L, Joffre R, Barthes BG (2008) Pairwise comparison of soil organic particle-size distributions in native savannas and Eucalyptus plantations in Congo. For Ecol Manag 255:1050-1056 
Delwaulle JC, Garbaye J, Laplace Y (1978) Un record de production forestière: les reboisements en eucalyptus hybrides de la savane côtière Congolaise. Rapport CTFT

Delwaulle JC, Garbaye J, Laplace Y (1981) Ligniculture en milieu tropical: les reboisements en eucalyptus hybrides de la savane côtière Congolaise. Rev For Fr 3:248-255

Derrien D, Plain C, Courty PE, Gelhaye L, Moerdijk T, Thomas F, Versini A, Zeller B, Koutika L-S, Boschker E, Epron D (2014) Does the addition of labile substrate destabilise old soil organic matter? Soil Biol Biochem 76:149-160

Dou X, Xu X, Shu X, Zhang Q, Cheng X (2016) Shifts in soil organic carbon and nitrogen dynamics for afforestation in Central China. Ecol Eng 87:263-270

Epron D, Mouanda C, Mareschal L, Koutika LS (2015) Impacts of organic residue management on the soil $C$ dynamics in a tropical eucalypt plantation on a nutrient poor sandy soil after three rotations. Soil Biol Biochem 85:183-189

Epron D, Nouvellon Y, Mareschal L, Moreira RM, Koutika LS, Geneste B, DelgadoRojas JS, Laclau JP, Sola G, Gonçalves JLM, Bouillet JP (2013) Partitioning of net primary production in Eucalyptus and Acacia stands and in mixed-species plantations: two case-studies in contrasting tropical environments. For Ecol Manag 301:102-111

Fornara D, Banin L, Crawley M (2013) Multi-nutrient versus nitrogen-only effects on carbon sequestration in grassland soils. Glob Chang Biol 19:3848-3857. https://doi.org/10.1111/gcb.12323

Forrester DI, Pares A, O'Hara C, Khanna PK, Bauhus J (2013) Soil organic carbon is increased in mixed-species plantations of Eucalyptus and nitrogen-fixing Acacia. Ecosystems 16:123-132

Galantini JA, Senesi N, Brunetti G, Rosell R (2004) Influence of texture on organic matter distribution and quality and nitrogen and Sulphur status in semiarid Pampean grassland soils of Argentina. Geoderma 123:143-152

Gonçalves JLM, Stape JL, Laclau J-P, Bouillet J-P, Ranger J (2008) Assessing the effects of early silvicultural management on long-term site productivity of fastgrowing eucalypt plantations: the Brazilian experience. South For 70:105-118

Hassink J (1997) The capacity of soils to preserve organic C and N by their association with clay and silt particles. Plant Soil 191:77-87

Hassink J, Bouwman LA, Zwart KB, Bloem J, Brussaard L (1993) Relationships between soil texture, physical protection of organic matter, soil biota, and $C$ and $\mathrm{N}$ mineralization in grassland soils. Geoderma 57:105-128

Inagaki M, Kamo K, Miyamoto K, Titin J, Jamalung L, Lapongan J, Miura S (2011) Nitrogen and phosphorus retranslocation and N:P ratios of litterfall in three tropical plantations: luxurious $\mathrm{N}$ and efficient $\mathrm{P}$ use by Acacia mangium. Plant Soil 341:295-307

Kirkby CA, Richardson AE, Wade LJ, Batten GD, Blanchard C, Kirkegaard JA (2013) Carbon-nutrient stoichiometry to increase soil carbon sequestration. Soil Biol Biochem 60:77-86

Kopittke PM, Dalal RC, Finn D, Menzies NW (2017) Global changes in soil stocks of carbon, nitrogen, phosphorus, and Sulphur as influenced by long-term agricultural production. Glob Chang Biol 23:2509-2519. https://doi.org/1 $0.1111 /$ gcb.13513

Koutika LS (2019) Afforesting tropical savannas with Acacia mangium and eucalyptus improves soil P availability in Arenosols of the Congolese coastal plains. Geoderma Reg 16:e00207. https://doi.org/10.1016/j. geodrs.2019.e00207

Koutika LS, Chone T, Andreux F, Burtin G, Cerri CC (1999) Factors influencing carbon decomposition of topsoils from the Brazilian Amazon Basin. Biol Fertil Soils 28:436-438

Koutika LS, Epron D, Bouillet JP, Mareschal L (2014) Changes in N and C concentrations, soil acidity and $\mathrm{P}$ availability in tropical mixed acacia and eucalypt plantations on a nutrient-poor sandy soil. Plant Soil 379:205-216

Koutika LS, Hauser S, Henrot J (2001) Soil organic matter assessment in natural regrowth, Pueraria phaseoloides and Mucuna pruriens fallow. Soil Biol Biochem 33:1095-1101

Koutika LS, Mareschal L (2017) Acacia and eucalypt change P, N and C concentrations in POM of arenosols in the Congolese coastal plains. Geoderma Reg 11:37-43. https://doi.org/10.1016/j.geodrs.2017.07.009

Koutika LS, Mareschal L, Epron D (2016) Soil P availability under eucalypt and acacia on Ferralic Arenosols, republic of the Congo. Geoderma Reg 7:153-158

Koutika LS, Sanginga N, Vanlauwe B, Weise S (2002) Chemical properties and soil organic matter assessment in fallow systems in the forest margins benchmark. Soil Biol Biochem 34:757-765

Koutika LS, Tchichelle SV, Mareschal L, Epron D (2017) Nitrogen dynamics in a nutrient-poor soil under mixed-species plantations of eucalypts and acacias. Soil Biol Biochem 108:84-90
Laclau JP, Ranger J, Deleporte P, Nouvellon Y, Saint André L, Marlet S, Bouillet JP (2005) Nutrient cycling in a clonal stand of eucalyptus and an adjacent savanna ecosystem in Congo: 3 . Input-output budget and consequences for the sustainability of the plantations. For Ecol Manag 210:375-391

Lal R (2004) Soil carbon sequestration to mitigate climate change. Geoderma 123:1-22

Lal R (2008) Carbon sequestration. Philos T Roy Soc B 363:815-830. https://doi. org/10.1098/rstb.2007.2185

Lal R (2014) Soil carbon management and climate change. In: Hartemink AE, McSweeney K (eds) Soil Carbon. Progress in Soil Science. Springer International, Switzerland, pp 339-361. https://doi.org/10.1007/978-3-319-04084-4-1

Li DZ, Niu SL, Luo YQ (2012) Global patterns of the dynamics of soil carbon and nitrogen stocks following afforestation: a meta-analysis. New Phytol 195:172-181

Makany L (1964) La côte atlantique du Congo cadres géographiques et géologiques, leur influence sur la répartition de la végétation et sur les possibilités agricoles du territoire. Symposium Science, Pekin, pp 891-907

Mareschal L, Nzila JDD, Turpault MP, M'Bou AT, Mazoumbou JC, Bouillet JP, Ranger J, Laclau JP (2011) Mineralogical and physico-chemical properties of Ferralic Arenosols derived from unconsolidated Plio-Pleistocenic deposits in the coastal plains of Congo. Geoderma 162:159-170

Marin-Spiotta E, Silver WL, Swanston CW, Ostertag R (2009) Soil organic matter dynamics during 80 years of reforestation of tropical pastures. Glob Chang Biol 15:1584-1597. https://doi.org/10.1111/j.1365-2486.2008.01805.x4

Pereira AP, de Andrade PA, Bini D, Durrer A, Robin A, Bouillet J-P, Andreote FD, EJBN C (2017) Shifts in the bacterial community composition along deep soil profiles in monospecific and mixed stands of Eucalyptus grandis and Acacia mangium. PLoS One 12(7):e0180371

Pereira APA, Zagatto MRG, Brandani CB, Mescolotti DL, Cotta SR, Gonçalves JLM, Cardoso EJBN (2018) Acacia changes microbial indicators and increases C and $\mathrm{N}$ in soil organic fractions in intercropped Eucalyptus plantations. Front Microbiol 9:655. https://doi.org/10.3389/fmicb.2018.00655

Pérez-Cruzado C, Mansilla-Salinero P, Rodríguez-Soalleiro R, Merino A (2012) Influence of tree species on carbon sequestration in afforested pastures in a humid temperate region. Plant Soil 353:333-353. https://doi.org/10.1007/s111 04-011-1035-0

Pieri CJMG (1989) Fertility of soils. A future for farming in the West African savannah. Springer-Verlag, Berlin

Platteau J, Bas L, Bernaerts E, Campens V, Carels K, Demuynck E, Hens M, Overloop S, Samborski V, Smets D, Van Gijseghem D, Vriesacker M, Wustenberghs H (2006) Landbouwbeleidsrapport 2005 (LARA), Afdeling Monitoring en Studie, D/2006/3241/155. Administratie, Departement Landbouw en Visserij, Brussels, p 240

R Core Team (2016) R: a language and environment for statistical computing. $R$ Foundation for Statistical Computing, Vienna http://www.R-project.org. Accessed 15 May 2019

Resh SC, Binkley D, Parrotta JA (2002) Greater soil carbon sequestration under nitrogenfixing trees compared with Eucalyptus species. Ecosystems 5:217-231

Sang PM, Lamb D, Bonner M, Schmidt S (2013) Carbon sequestration and soil fertility of tropical tree plantations and secondary forest established on degraded land. Plant Soil 362:187-200. https://doi.org/10.1007/s11104-012-1281-9

Schwartz D, Namri M (2002) Mapping the total organic carbon in the soils of the Congo. Glob Planet Chang 33:77-93

Shure J, Marien JN, de Wasseige C, Drigo R, Salbitano F, Dirou S, Nkoua M (2010) Contribution du bois énergie à la satisfaction des besoins énergétiques des populations d'Afrique Centrale: Perspectives pour une gestion durable des ressources disponibles. Office des publications de l'Union européenne, Luxembourg, pp 109-122

Sikora L, Yakovchenko V, Cambardella CA, Doran JW (1996) Assessing soil quality by testing organic matter. In: Magdoff FR, Tabatabai MA, Hanlon EA (eds.). Soil Organic Matter Analysis and Interpretation. Soil Science Society of America, Madison, pp 41-50

Stewart CE, Paustian K, Conant RT, Plante AF, Six J (2009) Soil carbon saturation: implications for measurable carbon pool dynamics in long-term incubations. Soil Biol Biochem 41:357-366

Tchichelle SV, Epron D, Mialoundama F, Koutika LS, Harmand JM, Bouillet JP, Mareschal L (2017) Differences in nitrogen cycling and soil mineralization between a eucalypt plantation and a mixed eucalypt and Acacia mangium plantation on a sandy tropical soil. South For 79(1):1-8. https://doi.org/10.2 989/20702620.2016.1221702 
Tiessen H, Moir JO (2008) Characterization of available P by sequential extraction. In: Carter MR, Gregorich EG (eds) Sampling and methods analyses, 2nd edn. Canadian Society of Soil Science CRC Press, Boca Raton, pp 293-306

Vanlauwe B, Nwokoe OC, Sanginga N, Merckx R (1999) Evaluation of methods for measuring microbial biomass $\mathrm{C}$ and $\mathrm{N}$ and their relationship with soil organic matter particle size classes for soils from the west-African moist savanna zone. Soil Biol Biochem 31:1071-1082

Voigtlaender M, Laclau J-P, Gonçalves JLM, Piccolo MC, Moreira MZ, Nouvellon Y, Ranger J, Bouillet J-P (2012) Introducing Acacia mangium trees in Eucalyptus grandis plantations: consequences for soil organic matter stocks and nitrogen mineralization. Plant Soil 352:99-111

Wander M (2004) Soil organic matter fractions and their relevance to soil function. In: Magdoff F, Weil R (eds) Advances in agroecology. CRC Press, Boca Raton, pp 67-102

\section{Submit your manuscript to a SpringerOpen ${ }^{\circ}$ journal and benefit from:}

- Convenient online submission

- Rigorous peer review

- Open access: articles freely available online

- High visibility within the field

- Retaining the copyright to your article

Submit your next manuscript at $\boldsymbol{\nabla}$ springeropen.com 